\title{
Chests in the Furniture Collection of the Ethnographic Museum in Zagreb - Processing, Digitisation and Opportunities
}

The paper is based on direct experience of processing and digitisation of chests from the Furniture Collection of the Ethnographic Museum in Zagreb. Quantitative (numerical) and qualitative data (descriptions, comparisons) has been presented that show the current status of the chests within the previously mentioned collection of the Museum. The paper lists further opportunities for professional processing and valorisation and interpretation of these objects in the future. Moreover, the paper provides historical development, typology and the role and the importance of chests as usable objects of traditional culture from the end of the $19^{\text {th }}$ and the beginning of the $20^{\text {th }}$ century.

Key words: Ethnographic museum (Zagreb)

museum collections, chests, processing of museum material

\section{INTRODUCTION}

One of the tasks ${ }^{1}$ that I was entrusted with during my professional development training (from October 2018 to October 2019) at the Ethnographic Museum in Zagreb was work on the Furniture Collection and Home Inventory managed by the museum advisor

1 In addition to the work on Furniture and Home Inventory Collection I participated in the organisation and implementation of museum hackathon: "Museum Hackathon: Hack Ethnographic Heritage!" $\left(1^{\text {st }}\right.$ and $2^{\text {nd }}$ December 2018), delivery of the lecture "What Kind of Museum Would You Like?" (6 $6^{\text {th }}$ April 2019) and ideation with students of ethnology and cultural anthropology from the Faculty of Humanities and Social Sciences in Zagreb, striving to explore the topics and objects of interest to the study group in the context of creation of permanent collection of the Museum, set up of the exhibitions "One Hundred Exhibits for One Hundred Years - The Treasure of the Ethnographic Museum", "Hat off! A story about (un) Covering the Head", I co-ordinated the exhibition "Traditional Head Coverings - Lika Cap and Basket Hat" $\left(29^{\text {th }}\right.$ September $-7^{\text {th }}$ October 2019), I participated in evacuation of museum collections because of the performance of construction work and in holding of educational workshops and guided tours of the permanent collection of the Museum. 
and my mentor, Zvjezdana Antoš, Ph.D. Among a large number of interesting objects in the Furniture Collection, my attention was primarily attracted by chests. In fact, the Ethnographic Museum preserves chests of different typology and origin and hence, as agreed with my mentor Zvjezdana Antoš, museum advisor, I decided to dedicate my paper primarily to these objects. The paper provides a historical overview, development and typology of chests as important usable objects in the traditional culture at the end of the $19^{\text {th }}$ and the beginning of the $20^{\text {th }}$ century, an overview of the condition of chests within the Furniture Collection, as well as the experience of work on their processing. It provides guidelines for further work and research and discusses the future of this museum object and its preservation in the context of the potential of the museum.

The literature that was primarily used included the work of the ethnologists Vlasta Domaćinović and Branka Vojnović-Traživuk who in their work were involved in the research of chests. Irrespective of the fact that it was published back in 1977, the book by Vlasta Domaćinović "Chests of Trimmed Boards in Yugoslavia", very systematically and in detail addressed this type of chest and provided an important factographic source (Domaćinović 1977). Branka Vojnović-Traživuk did a research on the Adriatic type of chests in her texts "The Bride's Chest Box" and "A Collection of Chests of the Ethnographic Museum of Split", published in the journal Ethnologica Dalmatica (Vojnović 1996, Vojnović-Traživuk 1997) and the catalogue "Beautiful and Rich: the Chests from the Ethnographic Museum in Split" (Vojnović-Traživuk, 2010). Out of the previously mentioned texts by the latter author, I primarily used a relatively recently published catalogue (2010) "Beautiful and Rich: the Chests from the Ethnographic Museum in Split". The latter catalogue, although used for the purpose of comparison of objects from the two museums, it was primarily intended as a source of information. In fact, the catalogue focused on research of the Adriatic chest that at the time had not been systematically and professionally addressed. In addition to the previously mentioned sources, the following catalogues were also used as important sources "Young Maro, Your Chest is Full" by Zvonimir Toldi (Toldi 2008), "Furniture in Croatia" by Zvjezdana Antoš (Antoš 1988), "Human Chests in Goriška Region” Inga Miklavčeč-Brezigar (MiklavčečBrezigar 2000) and "Kupčina Wedding" by Miško Mikulić and Mijo Konječić (Mikulić and Konječić 1990). Unfortunately, due to the current epidemiological situation I did not have the opportunity to consult the references ${ }^{2}$ that were not included in the Library of the Ethnographic Museum and whose information has not hence been included in this paper. The electronic media (the Internet) were used as a source of general information and significant help and support during the preparation of the paper in the form of professional advice and instructions was provided by my mentor, Zvjezdana Antoš, Ph.D. and the colleagues Aleksandra Vlatković, M. Sc., a documentarist and Domagoj Kačan, a restorer.

2 For example: Han 1960/1961. 


\section{HISTORY AND FUNCTION OF CHESTS}

The chest is the oldest object that was used for storage and keeping of different and frequently very valuable objects, primarily keeping in mind the very beginning of making of chests. The historical source of the chest as a storage of different valuables can be traced back to ancient civilisations. Ancient Egyptians loaded chests with jewellery, gold, linen and many other valuable and consecrated objects and buried them with their dead in order to enable them to own the previously mentioned objects also in the afterlife. Moreover, the Old Testament mentioned the Ark of the Covenant as the storage of the greatest valuable - the alliance with God (comp. Miklavčić-Brezigar 2000: 17, 23). The role of the chest as an object used for storage of very valuable things is shown also by its name that derives from the Latin word scrinium, which stands for an elongated round frame for paper storage, where important documents and records were stored (comp. Miklavčić-Brezigar 2000: 22). Furthermore, the use of the chest as the object intended for storage of important documents in the territory of what is currently known as Croatia is shown by the so-called Chest of Privileges that was made in 1643 as the storage place of the most important government documents of the Kingdom of Dalmatia, Croatia and Slavonia (comp. the Croatian State Archives 2020). It is important to point out that chests or sarcophaguses were used for burial in ancient times in Egypt, as well as later on in antiquity, which in our region exerted a significant influence. During the Middle Ages the chest became an irreplaceable furniture item in Europe, while it reached its pinnacle both from the functional and artistic aspect in Renaissance, primarily in the $16^{\text {th }}$ century. In Baroque they were gradually replaced by commodes, chests of drawers or wardrobes, only to almost cease being used in the $19^{\text {th }}$ century (comp. Vojnović-Traživuk 2010: 5).

In Croatian traditional culture chests remained in use throughout the $19^{\text {th }}$ until the beginning of the $20^{\text {th }}$ century. They were used as a storage for the traditional dress, in Croatian referred to as ruho, and other personal items. Nevertheless, there were also large chests that were used for grain storage. Irrespective of the fact that actual data has not been preserved, chests were normally made by local master artisans. They were normally custom-made and they were sold directly to the customer or in trade fairs (comp. Domaćinović 1977: 22). Depending on their purpose (military chest, sailors sea chest, different boxes etc.), as well as wishes and financing alternatives of the customer, decorations were used on chests to a lesser or greater extent. For example, sailors' sea chest was painted with motifs of ships, cypress trees, royal crowns or flags. In addition to sailors' sea chests, the most decorated chests were those intended as storage for ruho. They were decorated by carving and painting and the most common motifs were stylised flower vases, cypresses, leaves and different geometric ornaments (comp. Antoš 1998: 30).

A special importance in people's lives was attributed to the so-called hope chests - chests in which the bride carried her belongings (dowry, or in Croatian referred to as miraz, dota) to the groom's house when they got married. These chests had a special role in wedding customs and they were made with special attention. In addition to the dowry, they symbolised a covenant for wealth, abundance, luck and fertility in new married life 
(comp. Vojnović-Traživuk 2010: 10). In the Croatian territory there were many customs in connection with the hope chest. It was normally transported several days before the wedding and it was done publicly in the form of a joyous wedding parade. Nevertheless, depending on the region, it was sometimes also transported secretly (in the area around Buzet, the so-called odvoz banjka, in the local dialect) as it was a custom for young men of the village to try and stand in the way of those transporting it and also try to steal something from the carriage which they later on strived to sell for a specific price (comp. Vojnović 1997: 29, according to Mikac 1977). In Orebić and on the island of Korčula, with the songs, dancing and feasting, the chest was carried by four young men, yet they were never to put it down on the ground until they reached the groom's house (comp. Vojnović 1997: 29, according to Fisković 1971). The joyous wedding parade was also recorded in the Croatian region of Prigorje, and hence in Kupčina there were men in charge of carrying the chest, locally referred to as škrinjari who, together with the bride and groom, in the pompous parade on the carriage, went to take the bride's dowry, locally referred to as dota, which comprised of chests, a bed, a wardrobe, etc. (comp. Mikulić and Konječić 1990: 38). The hope chest (box) also appeared in songs that were sung during the transportation of the bridal belongings. In Slavonia, brides inherited the "dowry chest" from their mother and during its transportation to the groom's house the following song was normally sung:

"Chests are making an empty sound,

Mara is begging her mother to fill them in,

Dear mother tells dear Mara sweetly:

'Do not worry daughter Mara, your chest is full."”3

\section{THE CONDITION AND THE PLACEMENT OF THE CHESTS}

During my professional development at the Ethnographic Museum, besides working at the collection, I was also entrusted with a task of processing and digitisation of museum holdings from the Collections Home Inventory and Furniture. The process of digitisation in Modulor software for museums was implemented based on physical processing of objects in depots where my basic task was record keeping, measurement and photographic documentation of objects. During the work at the depot, records kept on objects with their corresponding photographs were entered into Modulor (if the record and the photograph of the object had not been previously entered) in accordance with the inventory cards of the Museum.

The Furniture Collection, in accordance with the print-out ${ }^{4}$ of the information entered in the documentation system Modulor, comprises of 633 objects. These are objects used in the basic home furnishings, such as beds, wardrobes, tables, commodes, cupboards,

3 Folk song lyrics written down by Luka Ilić Oriovačanin while writing about Slavonian wedding customs (Toldi 2008: 3).

4 The information was downloaded from the documentation system Modulor on the $21^{\text {st }}$ February 2020. 
mirrors, cradles and individual unusual items, such as a washing machine (the predecessor of the modern washing machine) or ice storage cabinet (the predecessor of the freezer). A total of 149 chests account for a significant proportion of this collection.

The term chest in this paper implies all the objects with an identical function, irrespective of the name that was used when the objects were entered in documentation cards and in Modulor. Hence, besides the chest, this overview also includes the objects entered under the names ${ }^{5}$ like coffer (kovčeg) and box (sanduk), since it is clear from object description that based on their form and function, they are actually chests, only another name was used to refer to them. During the work on furniture collection I kept records on and entered, measured and provided photographic evidence for a total of 149 chests. Out of the previously mentioned number of objects, there are 17 objects entered without the inventory tag ( $\mathrm{BB}$, no number). It has to be pointed out that the collection is currently being processed and prepared for registration and it was hence very difficult to gain insight into it. In fact, over time inventory numbers were lost or erased from the very objects, which additionally aggravated accurate documenting and processing of the collections and hence additional expertise of the head of the collection is required. In addition to the latter, another aggravating circumstance with chests, as well as with other voluminous objects inside the Furniture Collection and in other museum collections is a lack of adequate space for storage. In the Ethnographic Museum chests are stored in two depots and some items are exhibited in the permanent collection. One depot is located on the fifth floor and another is in the basement of the Museum. Chests have been placed in accordance with the fundamental principles of conservation of museum collections in both depots in such a manner that all the available space has been maximally exploited. Consequently, some items were absolutely inaccessible. The chests stored in the depot on the fifth floor were more easily processed as they were accessible. Simultaneously with professional development and work on the collection, evacuation of museum collections was also conducted due to the performance of construction work within the façade renovation and the preparation for the interior renovation and remodelling of the Museum and the situation was exploited in order to adequately document these objects. ${ }^{6}$ Unfortunately, the latter did not apply in the case of chests located in the basement of the Museum, which account for a larger share of the entire museum collection of chests in the Furniture Collection. Hence, in most cases, in the basement depot, due to the fact that they were inaccessible, it was not possible to fully examine individual and the largest objects and provision of photographic evidence proved a real challenge. Unfortunately, difficulties in terms of access and insufficient space between objects resulted in poor quality photographs that can only be used for inventory and as auxiliary documentation. In addition, it needs to be highlighted that during the work on documentation of chests, in addition to the colleague sculptor Domagoj Kačan, the restorer in charge of the collection, it was also

5 The issue of preparation of a thesaurus results from the problem of terminology of objects for the purpose of providing a highly realistic presentation and the possibilities for processing. Find out more in: Križaj 2017 and Kolbas 2006.

6 It needs to be pointed out that, irrespective of the fact that the objects located on the fifth floor were inaccessible, photographic documentation here, and in the basement depot, was prepared without adequate lighting and using a mobile device camera. 
necessary to involve the technician because of the weight and (in)accessibility of objects. Depending on the material (type of wood) used, their age, quality of craftsmanship and method of conservation, the chests have different preservation status - ranging from very well-preserved chests where restoration interventions have been performed, to those in need of restoration and conservation. Considering the complexity of the problem, inadequate storage and impossibility for further processing of objects, moving to new premises $^{7}$ will enable adequate storage, conservation and the forthcoming restoration work. Consequently, the specific objective of this paper is to provide an overview of chests within the Furniture Collection and it is striving to contribute to their further professional valorisation and interpretation in the future.

\section{TYPOLOGY OF CHESTS}

The chests that are being preserved in the Ethnographic Museum have different forms (typology) and their place and time of origin differ. Irrespective of their function, in accordance with their form, chests can be divided into three types - wooden chests made of trimmed boards (locally referred to as kobilaši and chests with slightly angled or flat lid), the Adriatic and the Dinaric type of chest (comp. Vojnović-Traživuk 2010: 6).

Wooden chests made of trimmed boards are characterised by a special method of construction where individual parts were made by fitting the boards into the feet and wooden wedges without the use of glue or iron (comp. Domaćinović 1977: 10). Within this type there are chests with slanted lid without horn-like protrusions on angles, typical of the Croatian regions of Posavina, Moslavina and Podravina, and chests with slanted lids and horn-like protrusions on angles typical in Slavonia (comp. Antoš 1998: 33). The type of chest with slanted lid and horn-like protrusions on angles is also locally referred to as kobilaš, kobilan. Chests made of trimmed boards can also have a flat lid and this type was primarily used in the western part of the country and in Istria. Their lid was normally decorated, as well as the front panel, while lateral sides were seldom decorated. Decorations included geometrical straight horizontal and vertical pairs of lines, as well as curved and zig zag lines and different circles and rosettes (comp. Domaćinović 1977: 18-24). Domaćinović stated that master chest makers (locally referred to as škrinjari) delivered the chests directly to the customers, who most frequently were the ones to have ordered them and hence "they never became an impersonal trade item....but each chest is unique and includes features of personality of its master maker" (Domaćinović 1977: 22).

The Adriatic type of chest includes chests whose surfaces were made of pieces of wood and they were fitted by mutually supplementing the indents of the lateral sides, locally referred to as vez na pero or swallow's tail. The lids of these chests were flat and their feet low in the form of stylised lion paws. The Adriatic type of chest was used in the south of Croatia and also throughout the Adriatic coast. The front panel of this

7 The Ethnographic Museum is implementing the project "Reconstruction of the Facility of the Abandoned Building of the National Ale House in Kačićeva Street" in order to provide premises for museum storage rooms, as well as an interactive depot and workshops that are to be functional by 2023. Find out more at: http://www.emz.hr/ Projekti/Projekt\%20obnove\%20muzeja (visited on $1^{\text {st }}$ May 2020). 
type of chest was decorated by carvings and sometimes even painted and the most common decorative forms were motifs of flowers, vases, birds, cypresses and different geometrical ornaments (comp. Vojnović-Traživuk 1995/1996: 28). Mirror symmetry of compositional motifs shows that there were most likely so-called patterns used by carpenters and woodcarvers to make them. Those most richly decorated were painted by painters, yet most of them were painted in carpenter's workshops where individual masters were in charge of their painting (comp. Vojnović-Traživuk 2010: 34-35).

The Dinaric chest, box or coffer (locally referred to as sanduk or kovčeg), is square shaped, while the lid and the sides are fitted with metal nails. This type of chest does not have any feet and the front side is decorated with carved geometric and floral motifs. The Dinaric chest is common in the Dinaric region, which is obvious from its name, i.e. in the south-eastern part of Croatia, as well as in Bosnia, Herzegovina and Montenegro (comp. Vojnović-Traživuk 2010: 7-9).

Most objects at the Museum originate from the territory of Croatia, with the exception of several objects from Bosnia and Herzegovina (5 objects), Kosovo (2 objects), Albania ( 2 objects) and Montenegro (1 object). In accordance with the dates stated on inventory cards, the chests preserved at the Museum were made from the mid-19 ${ }^{\text {th }}$ to the first half of the $20^{\text {th }}$ century, while the information about their author (master craftsman, chest maker or carpenter's workshop), with the exception of two objects, unfortunately has not been preserved or recorded. The provision of chests through purchase or in the form of donation, started immediately upon the foundation of the museum and it has continued to date. ${ }^{8}$ Nevertheless, most objects were provided from private persons until the 1990. Expectedly, the most common type of chests, since they were made in the Croatian regions of Posavina and Zagorje or the outskirts Zagreb, are chests made of trimmed boards. These are 72 objects $^{9}$ of different age, origin and subtypes (kobilaši, kobilani chests with flat or angled lid without turnbuckles) and various transitional shapes and versions of these subtypes. Chests made of trimmed boards were made in the broad area from the East (Slavonia and Baranja) through the central part of the country (Podravina and Moslavina) reaching to the West and the North of what is currently known as the Croatian territory. Examples of these chests that are currently preserved at the Ethnographic Museum prove a widespread presence of this type of chests. Hence some items were provided from the Croatian region of Zagorje (Stubički Laz - EMZ 8452, Razvor - EMZ 16249 etc.), Podravina (Koprivnica - EMZ 18527, Torčec - EMZ 4527, etc.), Posavina (Gornja Letina - EMZ 22715 etc.), the outskirts of Zagreb (Remete - EMZ 21376, Remetinec - EMZ 24249 etc.) and Slavonia (Viljevo Donje - EMZ 634 etc.), as well as from Istria (Markovac (Višnjan) - EMZ 14988). In addition to those from Croatia, it is important to highlight that two chests of trimmed boards from Kosovo have been preserved, which stand out compared with other chests, because of their different (coloured) ornaments.

$8 \quad$ The object entered in inventory book with the smallest inventory number (EMZ 594) was provided in 1921 and the one with the highest inventory number (EMZ 47240) in 2008.

9 The previously mentioned number does not include the objects whose typology cannot be defined due to a lack of photographic documentation, information or undefined descriptive data. 
The largest number of chests of trimmed boards at the Museum are those with flat or angled lid without turnbuckles. These are chests typical of the northern part of Croatia (Posavina, Podravina, Moslavina and Zagorje). The latter chests were decorated with shallow carved geometric patterns - straight, vertical, slanted and zig zag lines, as well as with circles and rosettes. In addition, chests were sometimes decorated by painting and with drawings. In the area of Slavonia and Baranja there are chests in which circle or rosette ornaments are painted in two colours (Antoš 1998: 33). The painted chests, such as the chest from Turopolje (EMZ 26684), are very rare (Fig. 1). Also, a large number of objects has not been decorated or only the chest lid has been decorated simply with overlapping slanted lines. Several items made in Slavonia are exception to the latter, as their ornaments are more deeply carved and similar to that in kobilaši, which is the most common chest subtype of trimmed wood in that area. The impact of the locality of manufacturing with a specific tradition of chest making is visible also on the objects originating from the Croatian region of Zagorje. In fact, almost all the chests that in accordance to the locality of manufacturing belong to the Croatian region of Zagorje were decorated, and in case of some objects, even their sides abound in ornaments. In the Croatian region of Zagorje, primarily in the area of Kraševec (Ivanec) near Lepoglava, the making of chests from trimmed boards was very developed and it was retained for quite long, which was also confirmed by the fact that the rural population from the outskirts of Zagreb (Resnik, Donja Greda) purchased their chests at the trade fair in Ivanec (comp. Domaćinović 1977: 29). Three chests from Kraševec (Ivanec) have been preserved at the Ethnographic Museum. One was provided in 1920 and it was made in the second half of the $19^{\text {th }}$ century and Vinko Kraš is mentioned as its maker (EMZ 1085), as well as two that were made at the beginning of the $20^{\text {th }}$ century and they were provided simultaneously in Ivanec in 1970 (EMZ 23143 and EMZ 23150). Based on his own research, Domaćinović stated that in the mid-20 ${ }^{\text {th }}$ century in Ivanec, three chest makers were still operating - Vinko Kraš, Videc Ćiril (Kraš) and Šlivarev Maler (comp. Domaćinović 1977: 49). It is interesting to point out that one of the two chests was purchased in 1970 from Ivanec, from Ćiril Kraš. Considering the previously mentioned, there is a possibility that this chest was made by Ćiril Kraš, as one of the last chest makers, irrespective of the fact that in the inventory card he was not entered as its maker. The chest (Fig. 2) is decorated with densely arranged and minutely elaborated motifs (triangle, leaf) which is indicative of a more recent origin of the object (comp. Domaćinović 1977: 24).

As already stated, typical chests from the area of Slavonia were locally referred to as kobilaš or kobilan. 17 objects ${ }^{10}$ were entered in Modulor under kobilaš, kobilan, kobilaš, mali cifrani and kobilaš uška. In addition to a large number of chests originating from Posavina, ${ }^{11}$ a significant number of objects was made in Slavonia and Baranja (Prkovci EMZ 20127, Branjin vrh - EMZ 19951, Slavonski Šamac - EMZ 5159 etc.) and they were primarily kobilaši. Kobilaši are simultaneously also the most decorative type of chests

10 Names taken from inventory cards have been entered into Modulor.

11 An increased number of objects from the previously mentioned area results from the fact that they were confiscated from Hans Georg Bien and included in Museum collections. 
made of trimmed boards. Each kobliaš has more or less rich deeply carved geometric ornaments (Fig. 3).

There are 11 objects of the Adriatic type of chest in Furniture Collection. This type of chest was used throughout the Adriatic coast and hence the collection includes objects originating from Kotor, Čilipi, Lumbarda, Benkovec, the Croatian Littoral and on the island of Lošinj. These are very interesting items in which rich decoration of the front surface is visible that is characteristic of this type of chest. They are decorated with motifs of stylised vases with flowers, leaves, cypresses, birds, temples and different geometric ornaments. Compared with the objects preserved at the Ethnographic Museum Split, it is evident that these are very similar objects made using patterns, as it has already been mentioned, which were then changed and adapted over time and from workshop to workshop. Hence, in case of objects EMZ 16954 (Fig. 4) and 630:SLT;2479, the front surface of the chest was decorated in an almost identical manner. Both chests are from Boka Kotorska (630:SLT;2479) or from Kotor (EMZ 16954) and they differ in terms of elaborateness of the very presentation. The central motif of the four-sided frame abounding in triangles is a pot-bellied floral vase with flowers (comp. VojnovićTraživuk 2010: 98). In case of the chest from the Museum in Split, it is a vase with thirteen flowers, while the object in Zagreb features eleven flowers. On each side of the upper circle part of the chest there is a bird and on the object from the Museum in Split, the birds are painted in red and yellow ochre. A similar situation repeats itself also on lateral motifs with mirror symmetry. It is the same composition, yet with a less clear and less detailed make on the object from the Ethnographic Museum in Zagreb. If the two chests are compared, there is a significant difference in the number of the birds, where the Zagreb-based chest has eight birds while on the Split-based chest there are twelve. Here it is most probably the case of a simplified pattern because the bird motif required a high level of technique of making and skill that is visible in the Split-based object, yet it is lacking on the Zagreb-based object.

The chest of Adriatic type implies a flat lid and stylised feet in the form of lion's paws and the interior was seldom decorated. In its centre there was a mirror and on each side of the mirror there were vases with flowers and birds. ${ }^{12}$ One such chest is preserved at the Ethnographic Museum in Zagreb (EMZ 18559) and it is included in its permanent collection. Motifs of vases with flowers, birds, cypresses and temples are interpreted as symbols of wedding, young girl-the bride, new life and fertility, i.e. they show that this is a chest for the bride - hope chest, dowry chest $\mathrm{t}^{13}$ (comp. Antoš 1998: 30).

The Dinaric type of chest accounts for the smallest number of items in Furniture Collection of the Ethnographic Museum and there is only one item. The chest or čekmeta (EMZ 13461) as it has been entered in Modulor, was made in Mostar and it was a typical example of this type of chests. In fact, the chest has no feet, it is of small dimensions and it has a decorated front side carved with geometric and floral shapes.

12 Vojnović-Traživuk considers these chests as a subtype of the Adriatic chests and refers to them as Dalmatian chests, and only 6 integral items have been preserved (comp.Vojnović-Traživuk 2010: 29).

13 Find out more about the symbolism of ornaments in: Bruck-Auffenberg 1912, Vojnović-Traživuk 2010 and Ban 2017. 
In addition to these three basic types of chests, the collection includes also a large number of other versions and subtypes of chests such as two nautical chests. In terms of construction, nautical chests are identical to the Adriatic type, yet they are normally of smaller dimensions and have characteristic ornaments different from the Adriatic type of chests. In fact, nautical chests are normally recognised by a characteristic painting on the front and in the internal part of the lid. Most frequently there are motifs of ships, cypresses, royal crowns or flags, which is confirmed by the object EMZ 15175 (Fig. 5). The previously mentioned symbols show the state for which a seaman or his ship is sailing. Unfortunately, the inventory card does not include detailed information about the origin of the chest itself or about its owner. In addition to nautical chests, the collection also includes wooden chests/trunks of trapezoid sides and flat lid which can often be secured with a chain - in Croatian referred to as sanduk okovanec ${ }^{14}$ such as the object EMZ 22740. Painted chests/trunks - in Croatian referred to as maljani sanduci are also very interesting. These painted chests have a flat lid and do not have feet and their sides are attached through indents locally referred to as na pero. They were most frequently painted into a darker colour (blue, red, brown etc.) onto which stylised floral ornaments were painted in lighter colours. This shape of the chest appears to have been the commonest in Slavonia (from where the two painted chests of the Ethnographic Museum originated, as well - EMZ 11315 and EMZ 12879). Nevertheless, the latter are considered as the cultural heritage of a broader, Alpine and Pannonian region. In fact, the chests decorated by painting were purchased on trade fairs where they had been brought by master craftsmen from the Croatian region of Zagorje, Slovenia and Austria (comp. Toldi 2008: 5). Their belonging to the same cultural and commercial circle is visible also in the mixture of different influences both in the making and design of chests. Based on the area from which they originated, the quality of the make and the knowledge of different construction types, some untypical items were also made. Hence the Furniture Collection also includes a chest from Gospić (Et 25392) which, in terms of its construction (locally referred to as vez na pero) corresponds to the Adriatic type. The latter chest, like Adriatic chests, has feet, not in the shape of lion's paws, but they are common boards. Among other things, the front surface was not decorated and the lid comprises of two boards. It needs to be kept in mind that both the appearance and the make were greatly influenced by the wealth of the region and the family ordering or buying the chest, as well as by the period in which it was made. Chest making changed over time against the backdrop of development and changes in living conditions. Consequently, in some examples, e.g. EMZ 19853ab, a change is visible in the construction of the chest and it reminds more of the form of the commode or chests of drawers (in Croatian referred to as ladice), which gradually supplanted the chest and assumed its function. 


\section{RESULTS AND ADDITIONAL OPPORTUNITIES}

During the work on processing of the chests, 149 objects were entered. Some objects, which had been digitally processed, were only added the corresponding documentation and a new digital record was provided for the objects that had not been documented in this manner. Unfortunately, due to many obligations, in addition to collections management, performed by the curators and as a result of construction work that had significantly affected the organisation of work at the Museum, during the course of my professional development I was not able to start the next stage of chest processing in the Furniture Collection with my mentor. It is primarily for this reason that the issue of objects without inventory tag ( $\mathrm{BB}$ - no number) has not been addressed. Concerning the objects without the recorded inventory tag, it needs to be determined whether the object has been included in the inventory and the inventory number subsequently lost /altered and whether the inventory number of the objects that had not been found belong to the objects stored in the depots without the inventory tag. It is a demanding process that requires considerable attention and co-ordination, as well as expertise of the collection manager. Irrespective of the fact that chests are no longer made, that their use has been decreasing in contemporary habitation and that they have been relatively well processed (Domaćinović - chests from trimmed boards, Vojnović-Traživuk - the Adriatic type of chests) research is always important, I dare say even necessary, in order to present and understand museum objects in greatest possible detail and against the backdrop both of our times and requirements. While considering the future of these objects it is impossible to avoid the issue of their adequate storage and preservation. I have already mentioned the voluminosity of objects as the basic problem in their adequate management and preservation. I believe most museums are faced with the problem of a lack of storage space for collections in accordance with the rules of professional practice, which is the most obvious primarily with objects of large dimensions and weight. The Ethnographic Museum is no exception. Notwithstanding the maximum adherence to the fundamental principles of preservation of museum collections (ensuring the microclimatic conditions, protection from biological pests...), the objects have been placed in two separated storage units (on the fifth floor and in the basement premises) and have been virtually placed one on top of the other in a confined space. It has to be pointed out that each conservation and restoration process, due to difficult access and transport of objects to restoration workshops is very demanding and for some items almost impossible. Nevertheless, new storage facilities envisaged through a project that has already been started, ${ }^{15}$ will solve the previously mentioned problems and enable adequate conservation of objects, ensuring the conditions for further research and hence greatly facilitate work on the collection.

Chests have huge potential in terms of exhibitions - with the exception of their size as an aggravating circumstance in terms of transport and technical realisation. In addition to the requirements of review or comparative exhibitions of chests or furniture, these objects can be exhibited in the context of many other topics. As previously stated, chests had an important role in wedding customs in the $19^{\text {th }}$ and at the beginning of

15 See note 7. 
the $20^{\text {th }}$ century. The hope chest and the objects in it were the dowry that the bride brought into marriage. However, besides this concrete value, the chest also had symbolic values. It symbolised a covenant for wealth, abundance, fertility and luck in married life and it can even nowadays be considered as a symbol of specific values and wishes, as well as through comparison with the current status symbols. Moreover, the previously mentioned objects can also have and they do have ${ }^{16}$ their place in the context of exhibitions addressing always actual topics such as wedding customs and marital life and currently very modern topics of interior decoration. The chest is a personal item which is evident in the example of dowry chest. Should one consider the dowry chest, it is clear that it is an intimate object of a young girl/woman (almost like lady's purse) in which she carries all her important belongings and valuables. It is possible to place and present the chest comparing it with the suitcase and travel as moving to the groom's house was probably the only "journey" taken by a young country girl in her entire life, for which she prepared herself. Simultaneously one should not ignore the potential of the chest as an example of technical artistry (handicraft) in wood processing as was shown in the exhibition entitled "Traditional Wood Processing" staged at the Museum in 1974. Consequently, there is a truly huge potential to use and exploit this object for exhibition purposes while addressing a wide range of interdisciplinary topics. Upon considerate design and implementation, the chest would certainly make an interesting exhibit for wider audiences who would hence, indirectly, be reminded of and taught about bygone times.

\section{CONCLUSION}

During the work on Furniture Collection 149 chests have been processed (entered, measured and photo documented). The information that has not been entered (most frequently photographs) has been included in the digital document Modulor or the latter was created if by then the entered object had not been digitised in the depot. Updating information and digitisation of objects are the prerequisites for the functioning and development of the museum in the current digital age and hence it is absolutely necessary.

Practical work with museum collections resulted in precious insight and work experience on the collection, which is one of the fundamental tasks of the curator. Among other things, questions were raised in connection with the further work process on the collection and processing and research in accordance with sound professional standards, which have aroused my interest and encouraged me to proceed in my own work and professional development.

A conclusion can be reached that chests proved very interesting as multifaceted objects with high potential for research and presentation within the broader context of interdisciplinarity.

16 For example at exhibitions: "The Bride in the Croatian Wedding Traditions" (27 $7^{\text {th }}$ June to $29^{\text {th }}$ September 1996). and "Furniture in Croatia - Interior Design from Ethnological Stance" (10 ${ }^{\text {th }}$ September 1998 to $25^{\text {th }}$ October 1998). 


\section{REFERENCES AND SOURCES:}

ANTOŠ, Zvjezdana. 1998. Pokućstvo u Hrvatskoj. Zagreb: Etnografski muzej.

BRUCK-AUFFENBERG, Natalija. 1912. Dalmacija i njena narodna umjetnost. Uzorci (šare) $i$ starinske umjetničke tehnike, upotrebljavane negda u narodu i Crkvi: čipke, vezovi, ćilimske tkanine, nakit, narodna nošnja i druge stvari, koje Dalmatinci nose i izradjuju. Beč: Anton Schroll\&Co.

DOMAĆINOVIĆ, Vlasta. 1977. Škrinje od tesanih dasaka u Jugoslaviji. Vinkovci: Općina Vinkovci.

HAN, Verena. 1960/1961. Umjetnička škrinja u Jugoslaviji od XIII. do XX. stoljeća. Beograd. Muzej primenjene umetnosti.

KOLBAS, Irena, 2006. “Tezaurus etnologije ali kulturne antropologije”. Etnološka istraživanja 11: 95-101.

KRIŽAJ, Lana. 2017. Tezaurus spomeničkih vrsta. Podatkovni standardi u inventarima graditeljske baštine. Zagreb: Mala biblioteka Godišnjaka zaštite spomenika kulture Hrvatske.

MIKLAVČĆĆ-BREZIGAR, Inga. 2000. Ljudske škrinje na Goriškem. Nova Gorica: Goriški muzej.

MIKULIĆ, Miško i Mijo KONJEČIĆ. 1990. Kupčinska svadba. Donja Kupčina: Zavičajni muzej Donja Kupčina.

TOLDI, Zvonimir. 2008. Kćeri Maro, sanduk tije pun. Slavonski Brod: Muzej Brodskog Posavlja.

VOJNOVIĆ, Branka. 1995/1996. "Nevjestina škrinja”. Ethnologica Dalmatica 4-5: 27-35.

VOJNOVIĆ-TRAŽIVUK, Branka. 1997. “Zbirka škrinja Etnografskog muzeja Split”. Ethnologica Dalmatica 6: 117-145.

VOJNOVIĆ-TRAŽIVUK, Branka. 2010. Lijepe i bogate: škrinje iz etnografskog muzeja Split. Split: Etnografski muzej.

"Hrvatski državni arhiv" Hrvatska enciklopedija, mrežno izdanje, 2020 <http://www.enciklopedija.hr/Natuknica.aspx?ID=26439> (visited on $1^{\text {st }}$ May 2020). 